\title{
Folliculitis following greater occipital nerve block
}

\author{
Semih DEĞERLil, ${ }^{1}$ Handan GÜLEÇ, ${ }^{1}$ Filiz KOÇ²
}

To the Editor,

Among headache syndromes cervicogenic headache is a common problem which originates from region of the neck. When wide range of pharmacological treatment options are inadequate, interventional procedures are applied. ${ }^{[1]}$ After trigger point injections, greater occipital nerve block (GONB) which is the most frequently applied technique among interventional methods has an important role in the treatment of cervicogenic headaches. ${ }^{[2]}$ Although the possibility of complication after GONB is very low, some side effects e.g. bleeding, infection, and allergic reactions can be seen after the application. ${ }^{[3]}$ Folliculitis is a skin condition which occurs with inflammation of the hair follicles. ${ }^{[4]}$ No report was obtained about association of GONB and folliculitis after an extensive database search. We report a case of folliculitis as a rare complication of GONB.

GONB was performed to a 29-year-old male patient who had complaint of right hemi-cranial and neck pain. After cleaning the skin and scalp with Polyvinylpyrrolidone-iodine, $3 \mathrm{ml}$ 1\% lidocaine was injected to region of the GON and then the area was massaged. Before and after the procedure visual analog scale (VAS) values were respectively 7 and 1 . However after 3 days follicles were detected throughout the bristled regions as nape and beard (Fig. 1). IV Ceftriaxone $1 \mathrm{~g}$ bid q5d and PO doxycycline 100 mg bid $\mathrm{q} 2 \mathrm{w}$ therapy was applied decisively. The patient was discharged at fifth day without any lesion. 5 days later he came back with complaints of mild hyperemia, warmth and tenderness at the right occipital region. He was treated with IV Daptomycin $500 \mathrm{mg}$ q1d and discharged one week later without any complaint or lesion.

Folliculitis occurs as a result of inflammatory diseases of the pilosebaceous follicle of the scalp. Infection, occlusion and irritation may cause folliculitis in superficial or deep placement. ${ }^{[4]}$ Swabs taken from the lesions for culture in the laboratory help to diagnose and to determine the infectious etiology. ${ }^{[5]}$ In this patient lesions observed in a vast area brought to mind an infectious pathology after the exclusion of occlusion and irritation. The result of laboratory culture was not significant enough as a guide. Nevertheless we have received a positive response to the initial empirical antibiotic therapy for Staphylo-

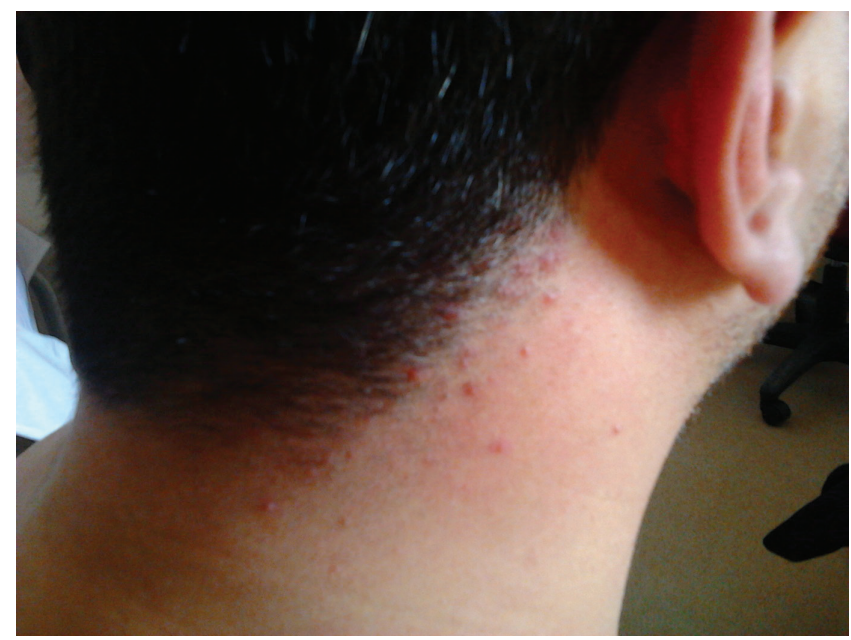

Figure 1. Papular lesions of folliculitis were appeared on the right side of the neck after greater occipital nerve block.

\footnotetext{
'Department of Anesthesiology, Kecioren Training and Research Hospital, Ankara;

2Department of Infectious Diseases, Kecioren Training and Research Hospital, Ankara, Turkey

${ }^{1}$ Keçiören Eğitim ve Araştırma Hastanesi, Anesteziyoloji Kliniği, Ankara;

${ }^{2}$ Keçiören Eğitim ve Araştırma Hastanesi, Infeksiyon Hastalıkları Kliniği, Ankara

Submitted (Başvuru tarihi) 25.06.2014 Accepted after revision (Düzeltme sonrası kabul tarihi) 14.08.2014

Correspondence (İletişim): Dr. Semih Değerli. Sanatoryum Caddesi, Ardahan Sokak, No: 1, 06350 Ankara, Turkey.

Tel: +90 - 312 - 3569000 e-mail (e-posta): drsemih@gmail.com
} 
coccus aureus which is the most common cause of bacterial folliculitis. ${ }^{[5]}$ The first lesions were in the superficial region of the skin, whereas the exacerbation found a place in deeper location with light characteristics of painful furuncles. An intravenous antibiotic therapy in the hospital was needed for the second stage of treatment process.

Some factors as insufficient skin cleansing, hidden follicles in the hair and intense venous structure of the scalp may be accused of the folliculitis formation. But comprehensive researches are needed to clarify these issues.

Consequently after GONB it is possible to occur folliculitis, therefore a close look with adequate skin cleansing before the procedure and an immediate and efficient therapy after formation of follicles are required.

\section{References}

1. Biondi DM. Cervicogenic headache: a review of diagnostic and treatment strategies. J Am Osteopath Assoc 2005;105(4 Suppl 2):16-22.

2. Naja ZM, El-Rajab M, Al-Tannir MA, Ziade FM, Tawfik OM. Repetitive occipital nerve blockade for cervicogenic headache: expanded case report of 47 adults. Pain Pract 2006;6(4):27884. CrossRef

3. Kerscher C, Zimmermann M, Graf BM, Hansen E. Scalp blocks. A useful technique for neurosurgery, dermatology, plastic surgery and pain therapy. [Article in German] Anaesthesist 2009;58(9):949-60. [Abstract] CrossRef

4. Luelmo-Aguilar J, Santandreu MS. Folliculitis: recognition and management. Am J Clin Dermatol 2004;5(5):301-10. CrossRef

5. Durdu M, Ilkit M. First step in the differential diagnosis of folliculitis: cytology. Crit Rev Microbiol 2013;39(1):9-25. CrossRef 